\title{
Effect of Memory Training Program on Memory Performance among Residents in Elderly Homes in Lattakia, Syria
}

\author{
Fatima Adnan Hallaj, Assistant Professor \\ Gerontological Nursing, Faculty of Nursing, Tishreen University, Syria
}

\begin{abstract}
One of the common issues facing older adults today is the fear of declining memory performance. Objective: Study the effect of memory training program on memory performance among residents in elderly homes in Lattakia, Syria. Setting: The study was carried out in the three available homes for elderly people. Subjects: The study subjects comprised 40 elderly persons. They were divided randomly into two groups: study and control. Each group comprised 20 elders. Elders in the control group were left to their routine while those in the study group were subjected to memory training for four months. Tools: Two tools were used for data collection: the socio-demographic and clinical data structured interview schedule, and the Blessed Information-Memory-Concentration (BIMC) Test. Results: The implemented memory training had a positive effect in improving memory performance among elders' in the study group where one fifth of them had no memory impairment while one fifth showed improvement in their status. Among the control group, the condition became worse for about a quarter of the subjects. Conclusion: The program succeeded in improving memory performance. Recommendations: Elderly homes should enforce the application of memory training to their residents into their daily routine to improve memory performance.
\end{abstract}

Keywords: Elderly; Memory performance; Memory training.

\section{Introduction}

People of all ages, in many cultures of the world, share the belief that memory declines with age including the idea that aging produces global and inevitable reductions in memory performance ${ }^{(1,2)}$. The findings from the longitudinal Health and Retirement Study showed that more than one third of elders have moderate to severe memory impairment ${ }^{(3,4)}$. On standardized tests of recent memory, it was found that on the average, healthy older adults in their $70 \mathrm{~s}$ and $80 \mathrm{~s}$ remember half as much information as younger adults in their teens and $20 \mathrm{~s}^{(5)}$.

The aging process is accompanied by changes in several types of memory ability, including the ability to remember information and events that happened a few hours or days ago (i.e., recent or short-term memory) and the ability to remember to do things in the future (i.e., prospective memory). Although, these memory changes are a normal part of aging, the extent and impact of these changes can be significant $^{(6-8)}$.

Such a decrease in memory ability can be associated with a wide range of consequences in everyday life, ranging from frustration or embarrassment at being unable to recall the name of an acquaintance to serious health risks associated with forgetting to take medications or attend medical appointments which affects' elders' performance of instrumental activities of daily living (IADL) (e.g., food preparation, driving, medication use). The accumulation of these limitations lead to increased risk of developing difficulties with basic activities of daily living, and that, taken together, these functional declines are associated with substantial declines in quality of life and increased risk of dementia, institutionalization, and mortality ${ }^{(9-11)}$.

Therefore, improving memory function might have short- and/or long-term effects on daily activities related to independent living and could have significant effects on general satisfaction 
with life by helping older individuals maintain healthy social relationships and active lifestyle ${ }^{(12-4)}$.

Mental stimulation, or exercises for the brain, helps maintain and enhance memory performance in daily life. ${ }^{(1,15)}$. Memory training interventions among older adults with no cognitive impairment seek to improve memory skills by teaching mnemonic techniques. Common internal mnemonic strategies include method of loci, association, categorization, visual imagery, face-name recognition and name-learning techniques, rehearsal, attention, number mnemonics, concentration, and story mnemonics. In addition, training programs often entail instruction in how to take advantage of environmental supports, called external memory aids. Combinations of these strategies are often taught in memory training programs ${ }^{(16-19)}$. A number of recommendations suggest that to get benefit from memory training the elders should participate in 45 minutes two times a week for a period of four months ${ }^{(20-22)}$.

The gerontological nurse plays an important role in enhancing and promoting elders' memory through offering stimulated environment rich with external memory aids. As well, she should creates ways to enable various levels of participation in memory stimulated activities that can be easily integrated into elders' everyday life $^{(23-25)}$.

Although cognitive health (memory) is an important marker of quality of life, no adequate attention is given in this respect in Syria. This study will draw additional document on memory training program as an effective element for improving memory performance among elderly population.

\section{Aim of the Study}

The aim of the study is to determine the effect of memory training program on memory performance among residents in elderly homes in Lattakia, Syria.

\section{Research Questions:}

The application of memory training program will improve memory performance among residents in elderly homes?

\section{Materials and Method}

\section{Materials}

Design: Quasi experimental study.

Setting: The study was carried out in all the three available residential homes for elderly people in Lattakia, Syria. These were Dar Al Ber, Dar Al Raha, and Dar Al Mowasat:

1- Dar El Ber: Accepts only male elders. The total number of residents is 45 elders.

2- Dar Al Raha: Accepts both male and female elders. The number of residents is 47 elders.

3- Dar Al Mowasat: Accepts only female elders. The number of residents is 52 elders.

Subjects: The study subjects comprised 40 elderly from both genders residing in the previous settings and fulfilling the following criteria: age 60 years and more, reporting memory impairment, mentally capable of understanding and performing the activities, no acute disease state, and agree to participate in the study.

Tools: Two tools were used to collect the data:

\section{Tool I: Socio-demographic and Clinical} Data Structured Interview Schedule

It was designed by the researcher after thorough review of literature and included the following data:

1- Data about the elders': Their socio demographic characteristics such as age, gender, social status, level of education, duration of stay in the home.

2- Health history: presence of chronic diseases and medication used.

Tool II: The Blessed InformationMemory-Concentration (BIMC) Test

This scale was developed by Katzman et al. $(1983)^{(26)}$, and used to evaluate cognitive domains including information, orientation, memory, attention, and 
concentration. It is composed of 26 questions. The score categories is evaluated according to the total number of errors, the total number of errors are summed up and score as the following:

- $<4$ errors

no impairment

- 4 - 10 errors mild impairment

- 11 - 16 errors moderate impairment

- $>16$ errors severe impairment.

Development of the memory training program:

This was developed by the researcher after thorough review of literature. Each elderly person attended an activation program (using internal mnemonic strategies and external memory aids) for four months (32 sessions). It includes two sessions per week. The time required for each session is 45 minutes.

\section{Method}

- Official approvals from the competent authorities to carry out the study were obtained.

- The study tools were validated by five experts in the field of the study. Arabic translation of tool II (The Blessed Information-Memory-Concentration

(BIMC) Test) was done by the researcher, validated and tested for its reliability using test retest method (after 2 weeks). It was applied to 20 elders. Spearman's correlation coefficient for BIMC was $r=0.89$.

- Informed consent from elders to participate in the study was obtained after explanation of the study purpose.

- A pilot study was conducted on five elders selected from Dar Al Mowasat to test the study tools. The necessary modifications were made based on the results of the pilot study. These elders were excluded from the study.

- Survey of all residents (144 elders) in the three homes was done in order to identify those fulfilling the study criteria. Those who reported having memory impairment were 64 elders, 5 of them refused to participate in the study and from the others the researcher selected 40 elders randomly using systematic sample technique, these were the study subjects.

- Each elder included in the study was interviewed individually to assess his memory status before the implementation of the program using tool II.

- The selected elders were assigned to two equal groups of 20 elders each (the study and control groups). Elders in the control group were left to their routine pattern while those in the study group were divided into four sub-groups. Each sub-group consisted of 3-5 elders.

\section{- Memory Training Program:}

- The researcher prepared the home environment to make it comfortable for the elders and help to stimulate their memory; windows were opened during daytime to allow sunlight in the rooms, provision of adequate light at night, use of pictures and external memory aids such as calendars and clocks in all rooms. Also, the researcher labeled the different rooms in the corridor such as bedrooms, living rooms, bathrooms and kitchens using distinctive colors to identify them from each other. Moreover, the elders' bedrooms were decorated with their photos and their family members, friends. Also, significant others, and each elder was asked to identify them by name, date of birth, and important occasions.

- Prior the implementation of the memory training, the researcher greeted the elders, introduced herself, gave a brief summary about the benefits, components and duration of the program. This helped the elders to cooperate with the researcher in the program. 
- During the different sessions, the researcher reviewed with each of the participants the important events he remembers about his life, e.g., infancy, preschool and school period, university and graduation, work, marriage, children,.....etc. emphasizing his achievement during each stage of life till retirement. In this respect, each elder was asked to present a brief summary about his life stages. Then, a discussion was carried out between the researcher, the elders, and participants emphasizing important events and his achievements during his life stages. This helped to maintain interaction and cooperation between them.

- During each of the sessions a short video film was projected. Elders were seated comfortably and asked to concentrate on the important events in the video. The film took about 5 to 10 minutes. Then, the researcher offered some cards with pictures showing the main idea of the film such as the historical events or the actors of the film. Each elder was asked to associate between the card and the film. This helped to motivate the elders to concentrate and recall the events. Incentives were given to the correct response.

- Also, elders were encouraged to join together in different games according to their performance such as cards, chess, backgammon, and crossword. The researcher observed the elder and his partner while playing, praised and encouraged them, and helped them when needed. This helped the elders to concentrate on the game, to compete with each other and to maintain communication and interaction with each other.

- The program was implemented in 32 sessions (two sessions per week). The study subjects were divided in groups of 3-5 elders of the same gender. Each session took about 45 minutes.

- Data collection started from the first of November 2017 to the end of February 2018.

- Evaluation of the program: After the implementation of the program, each of the participants in the two groups was reassessed to evaluate his memory status using tool II "The Blessed Information - Memory - Concentration (BIMC) Test".

- Data collection started from the first of November 2017 to the end of April 2018.

\section{Ethical considerations:}

Consent was obtained from each participant. Privacy and confidentiality of the collected data was assured. Each elderly was informed about his right to withdraw from the study without penalties.

\section{Statistical Analysis}

- All analyses were completed using the Statistical Package for the Social Sciences (SPSS) version 18 (IBM Corporation).

- Descriptive statistics using means (standard deviations) for continuous data and frequencies (\%) for categorical data were calculated.

- The chi-square and Fisher's exact tests were used to compare percentages between groups.

- The t-test was used to compare differences between continuous variables.

- P value less than 0.05 was considered to be statistically significant.

\section{Limitations of the study:}

- Five elders refused to join in the program.

- Two elders withdrew from the sessions and refused to complete the program. 
These were replaced by others to maintain the sample size.

\section{Results}

The 40 elders who participated in the study were $15(37.5 \%)$ from Dar Al Mowasat, 15 (37.5\%) from Dar Al Raha, and $10(25.0 \%)$ from Dar Al Ber.

Table (1) shows the socio-demographic characteristics of the elders. The age of the elders ranged from 65 to 85 years. The mean age of the study group was $72.5 \pm 5.3$ years and that of the control group was $72.1 \pm 5.5$ years. More than a half $(55.0 \%$ and $65.0 \%$ of the study and control groups respectively) were females. All of the study and control groups were educated where $60.0 \%$ and $45.0 \%$ of the study and control groups respectively had secondary or higher level of education. As regards occupation before retirement $35.0 \%$ and $25.0 \%$ of the study and control groups respectively were housewife; $20.0 \%$ and $40.0 \%$ respectively were employee; a quarter $(25.0 \%)$ of each of the two groups were technical worker. The duration of stay in the elderly home ranged from 1 to 12 years, with a mean of $5.55 \pm 2.76$ years for the study group and $5.1 \pm 2.36$ years for the control group.

Table (2) shows the health profile of elders in the two groups. No significant difference was found between the study and control groups with respect to all items of the health profile. It appears from the table that $15.0 \%$ and $10.0 \%$ of the study and control groups respectively reported having no chronic diseases, while for the rest in both groups cardiovascular disorders was the most common problem reported $(45.0 \%$ and $40.0 \%$ respectively); followed by musculoskeletal disorders $(25.0 \%$ and $15.0 \%$ respectively); metabolic disorders as DM $(20.0 \%)$ of each of the two groups; and GIT disorders $(20.0 \%$ and $15.0 \%$ respectively). Table also shows that $(15.0 \%)$ of each of the two groups do not take any medication, while the rest in both groups reported taking anti-hypertensive (40.0\% and $30.0 \%$ respectively); diuretic (30.0\% and $20.0 \%$ respectively); analgesics
(25.0\% and $15.0 \%$ respectively); digoxin $(25.0 \%$ and $15.0 \%$ respectively); and hypoglycemic $(20.0 \%)$ of each of the two groups.

Table (3) shows the mean scores of the memory status of the elders in both groups before and after 4 months. No significant difference was found between the study and control groups with respect to baseline memory performance before the implementation of the program. Applying the blessed information-memoryconcentration test on both groups four months after the implementation of the program the table shows improvement in the mean scores (decreased) from 14.25 to 11.95 in the study group while in the control group it became worse (increased) from 14.5 to 16.25 . The difference between the mean change in both groups was statistically significant $(\mathrm{P}=0.0001)$.

Table (4) applying the blessed information-memory-concentration test on the study group before and after four months from the implementation of the program the table shows that $66.7 \%$ of elders with mild impairment before the implementation of the program had no impairment after the program and $60.0 \%$ of those with moderate impairment showed improvement in their status after the program where they became mild impairment, and only $11.11 \%$ of those with severe state turned to the moderate state after the program. These differences were statistically significant $(\mathrm{P}=0.0001)$.

Table (5) applying the blessed information-memory-concentration test on the control group immediately after selection and four months later the table shows no improvement in their status. On the contrary, the condition worsened among many of them. Among the 6 elders with mild impairment one became worse after four months, it turned to moderate impairment. Also, two of the $6(33.33 \%)$ of those with moderate impairment changed to the severe impairment after four months and all those with severe impairment continued to be so. 
Table (6) shows the relation between the elders' characteristics among the study group and the changes in their memory status after the implementation of the program. The improvement in the memory status among elders who participated in the program was significantly associated with gender, age, duration of stay in the home, presence of diseases, vision disorders, and hearing disorders $(\mathrm{P}=0.0222, \mathrm{P}=0.0006$, $\mathrm{P}=0.0153, \mathrm{P}=0.0004, \mathrm{P}=0.0002, \mathrm{P}=0.0002$ respectively).

\section{Discussion}

A common misconception is that loss of cognitive abilities, memory, attention, and the other faculties that enable one to think clearly, maintain social relationships, and cope with normal age-related decline is inevitable and unalterable with aging persons. Recently researches gave closer attention to the importance of memory training in improving memory among elders $^{(27-29)}$. Accordingly, the aim of the study was to identify the effect of memory training program on improving memory performance among residents in elderly homes in Lattakia, Syria.

The study findings indicate a significant improvement in the memory status of elders after four months of the implementation of the memory training program (tables 3, 4 and 5). Comparing the elders' memory status before and after the program one can note an improvement among two fifth of elders in the study group where one fifth of them had no memory impairmentwhile one fifth showed improvement in their status. While among those in the control group memory declined significantly. Elders who participated in the program had no difficulty in recalling information including their age, when and where they were born, name of the home, street, and city where they live. As well, they were more oriented about the date, month, year, day of the week, time, and season. Also, they could easily recall information about special events and important dates in their life, place of household objects, phone numbers, and meetings and appointments. Moreover, they were more able to process information including count and calculation. In addition, they can do errands such as paying bills, feeding and watering pets or plants. Furthermore, this decrease was in the types of everyday memory errors which include repeating oneself, forgetting whether medication was already taken, or not, or if the stove was turned off.

This supports the findings of other studies. In Canada $(2001)^{(6)}$, a study reported improvement in every day memory functioning among participants in the study group than those in the control group. In USA $(2003)^{(27)}$ a study revealed that memory training such as telling story, using pictures, cross words significantly enhanced the ability to recall information. Another study in USA $(2006)^{(20)}$ proved that a quarter of elders who attended memory training had no memory impairment. Also in USA $(2014)^{(21,22)}$ two studies showed that training improved memory function in relation to performing instrumental activities of daily living. Moreover, they added that training had an immediate and long term effect on memory abilities where less difficulty was encountered in performing IADL such as management of medication and meal preparation. In addition, it is reported that social integration delays memory loss among elders where high levels of social integration predicted a slower rate of memory decline ${ }^{(4,5,11)}$.

The present study revealed that among the study group elders with mild, moderate or severe memory impairment showed improvement in their memory status (table 4 ), while among those in the control group no improvement was observed on the contrary they became worse (table 5). The same findings were reported in other studies $^{(20-21)}$. One can notice that memory training activities may improve or at least prevent the condition from getting worse. This improvement may be attributed to the effect of the memory training program which enhances the blood circulation in 
brain and increase amount of oxygen in the brain area. This will improve neurotransmitter activities which activate brain (i.e., neostriatum and cerebellum in addition to neocortex, prefrontal cortex, and frontal). These in turn, will enhance the process of recalling, speed of processing through sensory-motor elaboration and repetition. As for those with severe impairment (eight elders in the study group), they may require longer period of training to get the benefit. As for those in the control group, the lack of continuous stimulation and orientation in elderly homes put the elders at risk to develop mental dependency and accelerate the occurrence of mental problems.

Using memory exercise and practice help in improving the decline in memory as a result of age-related changes, teach people to use residual skills more efficiently through internal mnemonic strategies or rehearsal techniques repetition of information facilitate encoding. This improves elder's general skill for recollecting specific information useful for everyday memory tasks in the elders' population. Where using video with cards showing main ideas, dates, pictures help the elders to get the answer through links or connections formed between items with respect to time, environment, or specific item characteristics facilitate remembering. This structured sequence of images provides memory cues to facilitate recall. Face-name recognition help to remember names and faces together by integrating mnemonic devices like visual imagery, categorization, and association to link a person's name with his or her facial characteristics. The use of imagery aid memory indicates that targeting recollection can produce improvements in memory performance. Moreover, telling a story facilitates recalling, as it makes it come more readily to mind later. Repeating the story several times reflects an automatic, strengthening effect that arises from an earlier telling of the story. Also, playing games using numbers stimulate mental acuity, mental processing, and enhance performance. Also, external memory aids support memory, make elder oriented, and is applicable to a wide range of prospective memory tasks such as remembering appointments, medications, and tasks to be done. Finally, maximal improvement in memory functioning is obtained when group discussions allowing participants to be enjoyable and share their memory concerns and coping strategies. This usually enhances treatment gains.

The change in memory status is affected significantly by gender and age, where females showed better results and the younger the age the better the results (table $6)$. This is probably because of the effect of the aging process on memory where the remediation of age-related memory changes will increase as the population continues to age while those in younger age are less affected. The same was reported in other studies done in USA $(1999)^{(30)}$ and $(2009)^{(1)}$.

Furthermore, the study revealed that the shorter the duration of stay in the residential home the more improvement in the memory status among elders participating in the program activities (table 6). This may be explained by the fact that living in elderly homes impose inhabitants to have a sedentary lifestyle characterized by lack of physical activity, little social contact, and extended time spent in bed in addition to relocation stress syndrome. This in turn is usually associated with many problems such as loneliness, depression which affects elder's ability to recall and has negative consequence on memory. This supports another study ${ }^{(20)}$.

In addition, a significant relation was observed between the presence of diseases and the improvement in memory status, where elders with no diseases showed better improvement in memory (table 6). This can be due to the fact that the elders' medical condition itself or the side effects of the drugs may prevent or limit the potential benefits of the memory interventions. This result is in line with other studies ${ }^{(1,29)}$. 
The improvement in the memory status among elders who participated in the program was significantly associated with sensory deficits including vision and hearing disorders (table 6). This is expected because visual and hearing problems may increase the elders' vulnerability to memory decline where it hinders the elders' ability to use visual imagery which link concepts and items together with imagery to facilitate remembering. Also, hearing problems affects elders' ability to store information which is given to him. The same observation was reported in other studies $^{(1,14)}$

These sorts of interventions are enormously important. The effects of cognitive training interventions were substantial. There isn't a drug that will do that yet, and if there were, it would probably have to be administered with mental exercises. In the same way that physical training improves physical abilities, cognitive training (or brain training) improves cognitive (memory) abilities.

\section{Conclusion}

It can be concluded from the study that the application of memory training program resulted in positive improvement of the memory performance. This improvement is affected by many factors such as gender, age, duration of stay in the home, presence of medical diseases, vision and hearing disorders.

\section{Recommendations}

- Assessment of elders residing in the elderly homes is required to detect early those who show decline in memory, and to institute appropriate measures to overcome this problem.

- Create a stimulated environment rich with external memory aids such as lists, reminder notes, calendars, and messages to one's self.

- Elderly homes should schedule memory activities in their daily routine and encourage elders to share and take active role in these activities. 
Table (1): Distribution of elders in the study and control groups according to their sociodemographic characteristics

\begin{tabular}{|c|c|c|c|c|c|}
\hline \multirow{2}{*}{ Socio-demographic Characteristics } & \multicolumn{2}{|c|}{ Study group } & \multicolumn{2}{|c|}{ Control group } & \multirow[b]{2}{*}{ Significant } \\
\hline & $\begin{array}{c}\text { NO. } \\
\mathrm{n}=20\end{array}$ & $\begin{array}{c}\% \\
100\end{array}$ & $\begin{array}{c}\text { NO. } \\
\mathbf{n}=20\end{array}$ & $\begin{array}{c}\% \\
100\end{array}$ & \\
\hline $\begin{array}{c}\text { Age (in years): } \\
\text { - } \quad 60- \\
\text { - } 70- \\
\text { - } \quad 80-85\end{array}$ & $\begin{array}{c}6 \\
12 \\
2\end{array}$ & $\begin{array}{l}30.0 \\
60.0 \\
10.0\end{array}$ & $\begin{array}{c}7 \\
10 \\
3\end{array}$ & $\begin{array}{l}35.0 \\
50.0 \\
15.0\end{array}$ & $P=0.795$ \\
\hline Mean \pm SD & \multicolumn{2}{|c|}{$72.5 \pm 5.3$} & \multicolumn{2}{|c|}{$72.1 \pm 5.5$} & \\
\hline $\begin{aligned} \text { Sex: } & \\
\bullet & \text { Female } \\
\bullet & \text { Male }\end{aligned}$ & $\begin{array}{c}11 \\
9\end{array}$ & $\begin{array}{l}55.0 \\
45.0\end{array}$ & $\begin{array}{c}13 \\
7\end{array}$ & $\begin{array}{l}65.0 \\
35.0\end{array}$ & $\mathrm{P}=0.519$ \\
\hline \begin{tabular}{|l} 
Educational Level: \\
- Up to preparatory \\
- $\quad$ Secondary \\
- \\
Higher education \\
\end{tabular} & $\begin{array}{c}8 \\
11 \\
1 \\
\end{array}$ & $\begin{array}{c}40.0 \\
55.0 \\
5.0 \\
\end{array}$ & $\begin{array}{c}11 \\
5 \\
4 \\
\end{array}$ & $\begin{array}{l}55.0 \\
25.0 \\
20.0\end{array}$ & $\mathrm{P}=0.104$ \\
\hline \begin{tabular}{|l} 
Occupation before retirement: \\
- Housewife \\
- Employee \\
- Technical worker \\
- Business \\
\end{tabular} & $\begin{array}{l}7 \\
4 \\
5 \\
4\end{array}$ & $\begin{array}{l}35.0 \\
20.0 \\
25.0 \\
20.0\end{array}$ & $\begin{array}{l}5 \\
8 \\
5 \\
2\end{array}$ & $\begin{array}{l}25.0 \\
40.0 \\
25.0 \\
10.0\end{array}$ & $\mathrm{P}=0.506$ \\
\hline 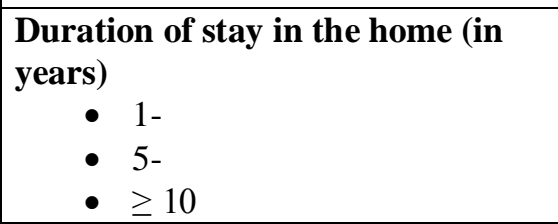 & $\begin{array}{c}7 \\
12 \\
1\end{array}$ & $\begin{array}{c}35.0 \\
60.0 \\
5.0\end{array}$ & $\begin{array}{c}10 \\
9 \\
1\end{array}$ & $\begin{array}{c}50.0 \\
45.0 \\
5.0 \\
\end{array}$ & $\mathrm{P}=0.619$ \\
\hline Mean \pm SD & 5.55 & 2.76 & 5.1 & .36 & \\
\hline
\end{tabular}

* Significant $P \leq 0.05$ 
Table (2): Distribution of elders in the study and control groups according to their health profile

\begin{tabular}{|c|c|c|c|c|c|}
\hline \multirow{2}{*}{ Health Profile } & \multicolumn{2}{|c|}{ Study group } & \multicolumn{2}{|c|}{ Control group } & \multirow{2}{*}{$\begin{array}{c}\text { Test of } \\
\text { Significance }\end{array}$} \\
\hline & $\begin{array}{c}\text { NO. } \\
\mathrm{n}=20\end{array}$ & $\begin{array}{c}\% \\
100\end{array}$ & $\begin{array}{c}\text { NO. } \\
\mathrm{n}=\mathbf{2 0}\end{array}$ & $\begin{array}{c}\% \\
100\end{array}$ & \\
\hline $\begin{array}{c}\text { Vision disorders: } \\
\text { - No } \\
\text { - Yes }\end{array}$ & $\begin{array}{c}7 \\
13\end{array}$ & $\begin{array}{l}35.0 \\
65.0\end{array}$ & $\begin{array}{c}13 \\
7\end{array}$ & $\begin{array}{l}65.0 \\
35.0\end{array}$ & $\mathrm{P}=0.58$ \\
\hline $\begin{array}{c}\text { Hearing disorders: } \\
\text { - No } \\
\text { - Yes } \\
\end{array}$ & $\begin{array}{c}11 \\
9 \\
\end{array}$ & $\begin{array}{l}55.0 \\
45.0 \\
\end{array}$ & $\begin{array}{c}16 \\
4 \\
\end{array}$ & $\begin{array}{l}80.0 \\
20.0 \\
\end{array}$ & $\mathrm{P}=0.091$ \\
\hline $\begin{array}{ll}\text { Diseases: \# } \\
\text { - None } \\
\text { - } \quad \text { Cardiovascular disorders } \\
\text { - Musculoskeletal disorders } \\
\text { - Metabolic disorders (DM) } \\
\text { - } \text { GIT disorders } \\
\text { - } \quad \text { Urinary disorders }\end{array}$ & $\begin{array}{l}3 \\
9 \\
5 \\
4 \\
4 \\
2\end{array}$ & $\begin{array}{l}15.0 \\
45.0 \\
25.0 \\
20.0 \\
20.0 \\
10.0\end{array}$ & $\begin{array}{l}2 \\
8 \\
3 \\
4 \\
3 \\
1\end{array}$ & $\begin{array}{c}10.0 \\
40.0 \\
15.0 \\
20.0 \\
15.0 \\
5.0\end{array}$ & $\begin{array}{c}\mathrm{P}=0.633 \\
\mathrm{P}=0.749 \\
\mathrm{P}=0.705 \\
\mathrm{P}=1 \\
\mathrm{P}=0.077 \\
\mathrm{P}=0.533\end{array}$ \\
\hline $\begin{array}{l}\text { Drugs: \# } \\
\text { - None } \\
\text { - Anti-hypertensive } \\
\text { - Diuretic } \\
\text { - Anti-inflammatory and analgesics } \\
\text { - Higoxin } \\
\text { - Anpoglycemic } \\
\text { - Antibiotic } \\
\text { - Laxative } \\
\text { - Vitamins }\end{array}$ & $\begin{array}{l}3 \\
8 \\
6 \\
5 \\
5 \\
4 \\
2 \\
1 \\
1 \\
1\end{array}$ & $\begin{array}{l}15.0 \\
40.0 \\
30.0 \\
25.0 \\
25.0 \\
20.0 \\
10.0 \\
5.0 \\
5.0 \\
5.0\end{array}$ & $\begin{array}{l}3 \\
6 \\
4 \\
3 \\
3 \\
4 \\
1 \\
1 \\
0 \\
1\end{array}$ & $\begin{array}{c}15.0 \\
30.0 \\
20.0 \\
15.0 \\
15.0 \\
20.0 \\
5.0 \\
5.0 \\
0.0 \\
5.0\end{array}$ & $\begin{array}{c}\mathrm{P}=1 \\
\mathrm{P}=0.705 \\
\mathrm{P}=0.356 \\
\mathrm{P}=0.645 \\
\mathrm{P}=0.645 \\
\mathrm{P}=1 \\
\mathrm{P}=0.311 \\
\mathrm{P}=1 \\
\mathrm{P}=0.147 \\
\mathrm{P}=1\end{array}$ \\
\hline
\end{tabular}

* Significant $P \leq 0.05$

\# More than one answer

Table (3): Mean scores obtained by elders according to the Blessed InformationMemory-Concentration Test in both groups before and four months after the implementation of nursing interventions

\begin{tabular}{||l|c|c|c||}
\hline Blessed Information-Memory- & Study group & Control group & \multirow{2}{*}{ P value } \\
\cline { 2 - 3 } Concentration Test & Mean \pm SD & Mean \pm SD & \\
\hline - Before & $14.25 \pm 5.36$ & $14.5 \pm 6.24$ & $\mathrm{P}=0.8927$ \\
- After 4 months & $11.95 \pm 7.66$ & $16.25 \pm 8.33$ & $\mathrm{P}=0.0977$ \\
\hline Mean change \pm SD & $2.3 \pm 2.7$ & $-1.75 \pm 2.59$ & $\mathrm{P}=0.0001$ \\
\hline
\end{tabular}

* Significant $P \leq 0.05$ 
Table (4): Distribution of elders in the study group according to their memory status before and four months after the implementation of nursing interventions

\begin{tabular}{|c|c|c|c|c|c|c|c|c|c|c|c|}
\hline \multirow{3}{*}{\multicolumn{3}{|c|}{$\begin{array}{l}\text { Blessed Information-Memory- } \\
\text { Concentration Test }\end{array}$}} & \multicolumn{8}{|c|}{$\begin{array}{l}\text { Memory status after } 4 \text { months } \\
(\text { n. }=20)^{2}\end{array}$} & \multirow{3}{*}{$P$ value } \\
\hline & & & \multicolumn{2}{|c|}{ No } & \multicolumn{2}{|c|}{$\begin{array}{c}\text { Mild } \\
\text { impairment }\end{array}$} & \multicolumn{2}{|c|}{$\begin{array}{c}\text { Moderate } \\
\text { impairment }\end{array}$} & \multicolumn{2}{|c|}{$\begin{array}{c}\text { Severe } \\
\text { impairment }\end{array}$} & \\
\hline & & & No. & $\%$ & No. & $\%$ & No. & $\%$ & No. & $\%$ & \\
\hline \multirow{3}{*}{$\begin{array}{l}\text { Memory } \\
\text { status } \\
\text { before }\end{array}$} & $\begin{array}{l}\text { Mild } \\
\text { impairment }\end{array}$ & $\begin{array}{l}\text { No. } \\
n=6\end{array}$ & 4 & 66.7 & 2 & 33.3 & & & & & \multirow{3}{*}{$\mathrm{P}=0.0001 *$} \\
\hline & $\begin{array}{l}\text { Moderate } \\
\text { impairment }\end{array}$ & $\begin{array}{l}\text { No. } \\
n=5\end{array}$ & & & 3 & 60.0 & 2 & 40.0 & & & \\
\hline & $\begin{array}{l}\text { Severe } \\
\text { impairment }\end{array}$ & $\begin{array}{l}\text { No. } \\
n=9\end{array}$ & & & & & 1 & 11.11 & 8 & 88.89 & \\
\hline
\end{tabular}

* Significant $P \leq 0.05$

Table (5): Distribution of elders in the control group according to their memory status before and after four months

\begin{tabular}{|c|c|c|c|c|c|c|c|c|c|c|c|}
\hline \multirow{3}{*}{\multicolumn{3}{|c|}{$\begin{array}{l}\text { Blessed Information-Memory- } \\
\text { Concentration Test }\end{array}$}} & \multicolumn{8}{|c|}{$\begin{array}{c}\text { Memory status after } 4 \text { months } \\
(\text { n. }=20)^{20}\end{array}$} & \multirow{3}{*}{$P$ value } \\
\hline & & & \multicolumn{2}{|c|}{ No } & \multicolumn{2}{|c|}{$\begin{array}{c}\text { Mild } \\
\text { impairment }\end{array}$} & \multicolumn{2}{|c|}{$\begin{array}{c}\text { Moderate } \\
\text { impairment }\end{array}$} & \multicolumn{2}{|c|}{$\begin{array}{c}\text { Severe } \\
\text { impairment }\end{array}$} & \\
\hline & & & No. & $\%$ & No. & $\%$ & No. & $\%$ & No. & $\%$ & \\
\hline \multirow{3}{*}{$\begin{array}{l}\text { Memory } \\
\text { status } \\
\text { before }\end{array}$} & $\begin{array}{l}\text { Mild } \\
\text { impairment }\end{array}$ & $\begin{array}{l}\text { No. } \\
n=6\end{array}$ & 5 & 83.33 & 1 & 16.67 & & & 5 & 83.33 & \multirow{3}{*}{$\mathrm{P}=0.0001 *$} \\
\hline & $\begin{array}{l}\text { Moderate } \\
\text { impairment }\end{array}$ & $\begin{array}{l}\text { No. } \\
n=6\end{array}$ & & & 4 & 66.67 & 2 & 33.33 & & & \\
\hline & $\begin{array}{l}\text { Severe } \\
\text { impairment }\end{array}$ & $\begin{array}{l}\text { No. } \\
\mathrm{n}=8\end{array}$ & & & & & 8 & 100.0 & & & \\
\hline
\end{tabular}

*Significant at $P \leq 0.05$ 
Table (6): Relation between the elders' characteristics of the study group and the changes in their memory status before and four months after the implementation of nursing interventions

\begin{tabular}{|c|c|c|c|}
\hline \multirow{3}{*}{ Elders' characteristics } & \multicolumn{2}{|c|}{ Study group } & \multirow{3}{*}{$P$ value } \\
\hline & Before & After & \\
\hline & Mean score \pm SD & Mean score \pm SD & \\
\hline $\begin{array}{l}\text { Gender: } \\
\text { - } \quad \text { Female } \\
\text { - Male }\end{array}$ & $\begin{array}{l}13.09 \pm 5.92 \\
15.66 \pm 4.52\end{array}$ & $\begin{array}{l}11.18 \pm 8.08 \\
12.88 \pm 7.49\end{array}$ & $\begin{array}{l}\mathrm{P}=0.0222^{*} \\
\mathrm{P}=0.0375^{*}\end{array}$ \\
\hline $\begin{array}{c}\text { Age in years: } \\
\bullet \quad<75 \\
\bullet \quad \geq 75 \\
\end{array}$ & $\begin{array}{l}12.31 \pm 5.57 \\
17.85 \pm 2.41 \\
\end{array}$ & $\begin{array}{c}8.76 \pm 7.67 \\
17.85 \pm 2.41 \\
\end{array}$ & $\begin{array}{c}\mathrm{P}=0.0006^{*} \\
\mathrm{P}=- \text { non-calculable }\end{array}$ \\
\hline $\begin{array}{c}\text { Duration of stay in the home: } \\
\bullet \quad<5 \text { years } \\
\bullet \quad \geq 5 \text { years }\end{array}$ & $\begin{array}{l}11.14 \pm 5.75 \\
15.92 \pm 4.51\end{array}$ & $\begin{array}{c}8 \pm 7.59 \\
14.07 \pm 7.08\end{array}$ & $\begin{array}{c}\mathrm{P}=0.0153^{*} \\
\mathrm{P}=0.429\end{array}$ \\
\hline $\begin{array}{l}\text { Presence of diseases: } \\
\text { - Yes } \\
\bullet \quad \text { No }\end{array}$ & $\begin{array}{c}11.5 \pm 5.09 \\
18.37 \pm 2.26\end{array}$ & $\begin{array}{c}7.66 \pm 6.94 \\
18.37 \pm 2.26\end{array}$ & $\begin{array}{c}\mathrm{P}=0.0004^{*} \\
\mathrm{P}=- \text { non-calculable }\end{array}$ \\
\hline $\begin{array}{l}\text { Vision disorders: } \\
\text { - No } \\
\text { - } \quad \text { Yes }\end{array}$ & $\begin{array}{c}8 \pm 2.64 \\
17.61 \pm 2.66\end{array}$ & $\begin{array}{c}3.28 \pm 2.69 \\
16.61 \pm 4.69\end{array}$ & $\begin{array}{c}\mathrm{P}=0.0002^{*} \\
\mathrm{P}=0.1668\end{array}$ \\
\hline $\begin{array}{c}\text { Hearing disorders: } \\
\qquad \text { No } \\
\text { - Yes } \\
\end{array}$ & $\begin{array}{c}10.9 \pm 4.84 \\
18.33 \pm 2.23\end{array}$ & $\begin{array}{c}6.72 \pm 6.40 \\
18.33 \pm 2.23\end{array}$ & $\begin{array}{c}\mathrm{P}=0.0002 * \\
\mathrm{P}=- \text { non-calculable }\end{array}$ \\
\hline
\end{tabular}

*Significant at $P \leq 0.05$ 


\section{References}

1. Mcdougall G. A framework for cognitive interventions targeting everyday memory performance and memory self-efficacy. Fam community Health 2009; 32(1): 15-26.

2. Smith G, Housen P, Yaffe K, Ruff R, Kennison R, Mahncke H, Zelinski E. A cognitive training program based on principles of brain plasticity: results for the improvement in memory with plasticity-based adaptive cognitive training (IMPACT) study. Journal of the American Geriatrics Society 2009; 57(1): 594-603.

3. Federal Interagency Forum on Aging Related Statistics. Older Americans: key indicator of wellbeing. Washington DC: US Government Printing Office; 2004.

4. Rebok G, Ball K, Guey L, Jones R, Kim H, King J, Willis S. Ten-year effects of the ACTIVE cognitive training trail on cognition and everyday functioning in older adults. Journal of the American Geriatrics Society 2014; 62(1): 16-24.

5. Ertel K, Glymour M, Berkman L. Effects of social integration on preserving memory function in a nationally representative US elderly population. American Journal of Public Health 2008; 98(7): 1215- 20.

6. Troyer A. Improving memory knowledge, satisfaction, and functioning via an education and intervention program for older adults. Adams State University 2014; 12(14): 256268.

7. Gross A, Parisi J, Spira A, Kueider A, Ko J, Saczynski J, Rebok G. Memory training interventions for older adults: a metaanalysis. Aging and Mental Health 2012; 16(1): 722-34.

8. Zelinski E, Spina L, Yaffe K, Ruff R, Kennison R, Mahncke H, Smith G. Improvement in memory with plasticitybased adaptive cognitive training: results of the 3 month follow up. Journal of the American Geriatrics Society 2011; 59(1): 258-265.

9. Whitlock L, Mclaughlin A, Allaire J. Individual differences in response to cognitive training; using a multi-modal, attentionally demanding, game- based intervention for older adults. Computers in Human Behavior 2012; 28(1): 1091-6.

10. Anderson-Hanley C, Arciero P, Brickman A, Nimon J, Okuma N, Westen S, Zimmerman E. Exergaming and older adult cognition: a cluster randomized clinical trail. American Journal of Preventive Medicine 2011; 42(2): 109-19.

11. Gross A, Rebok G. Memory training and strategy use in older adults: results from the ACTIVE study. Psychology and Aging 2011; 26(1): 503-17.

12. Connor L. Memory in old age: patterns of decline and preservation. Seminars in Speech and Language 2001; 22(2): 117-25.

13. Worthen J, Hunt R. Mnemonology; mnemonics for the $21^{\text {st }}$ century. Hove East Sussex Psychology Press 2011; 1 (1): 12-21.

14. Borella E, Carretti B, Cantarella A, Riboldi F, Zavagnin M, De Beni R. Benefits of training visuospatial working memory in young-old and old-old. Dev Psychol 2014; 50(3): 71427.

15. Bellander M, Eschen A, Lövdén M, Martin M, Bäckman L, Brehmer Y. No evidence for improved associative memory performance following process-based associative memory training in older adults. Front Aging Neurosci 2016; 8(1): 326- 8

16. Gross A, Parisi J, Spira A, Kueider A, Ko J, Saczynski J, Samus Q, Rebok G. Memory training interventions for older adults: a metaanalysis. Aging \& Mental Health 2012; 16(6): 722-34.

17. Woolverton m, Scogin F, Shackelford J, Black $\mathrm{S}$, Duke L. Problem-targeted memory training for older adults. Aging Neuropsychology and Cognition 2010; 8(4): 241-55.

18. Dahlin E, Bäckman L, Neely A, Nyberg L. Training of the executive component of working memory: subcortical areas mediate transfer effects. Restor Neurol Neurosci 2009; 27(5): 405-19. 
19. Zinke K, Zeintl M, Rose N, Putzmann J, Pydde A, Kliegel M. Working memory training and transfer in older adults: effects of age, baseline performance, and training gains. Dev Psychol 2014; 50(1): 304-15.

20. Wolinsky F, Unverzagt F, Smith D, Jones R, Wright E, Tennstedt $\mathrm{S}$. The effects of the ACTIVE cognitive training trail on clinically relevant declines in health-related quality of life. Journal of Gerontology: Social Sciences 2006; 6(5): 281-7.

21. Rebok G. Ball K. Ten-year effects of the ACTIVE cognitive training trail on cognition and everyday functioning in older adults. J Am GeriatrSoc 2014; 62(1): 16- 24.

22. Kueider A, Bichay K, Rebok G. Cognitive training for older adults: what is it and does it work?. Center on aging at American Institutes for Reearch 2014; 10(1): 1-8.

23. Borella E, Carretti B, Riboldi F, De Beni R. Working memory training in older adults: evidence of transfer and maintenance effects. Psychol Aging 2010; 25(4): 767-78.

24. Payne BR, Stine-Morrow E. The effects of home- based cognitive training on verbal working memory and language comprehension in older adulthood. Front Aging Neurosci 2017; 8(9): 256-9.
25. Grönholm-Nyman P, Soveri A, Rinne JO, Ek E, Nyholm A, Stigsdotter $\mathrm{N}$, Laine $\mathrm{M}$. Limited effects of set shifting training in healthy older adults. Front Aging Neurosci 2017; 23(9): 69-72.

26. Katzman R, Brown T, Fuld P. Validation of a short orientation-memory-concentration test of cognitive impairment. Am J Psychiatry 1983; 140: 734- 9 .

27. Jennings J, Jacoby L. Improving memory in older adults: training recollection. Neuropsychological Rehabilitation 2003; 13(4): 417-440.

28. Borella E, Carbone E, Pastore M, De Beni R, Carretti B. Working memory training for healthy older adults: the role of individual characteristics in explaining short- and longterm gains. Front Hum Neurosci 2017; 22(11): 99-104.

29. Mcdougall G, Becker H, Pituch K, Vaughan $\mathrm{P}$, Acee $\mathrm{T}$, Delville $\mathrm{C}$. The senior WISE study; improving everyday memory in older adults. Archives of Psychiatric Nursing 2010; 24(1): 291- 306.

30. Rasmusson D, Rebok G,Bylsma F, Brandt J. Effects of three types of memory training in normal elderly. Aging Neuropsychology and cognition 1999; 6(1): 56-66. 